\title{
A case of tracheal foreign body encountered in a Kangal dog: clinical, radiological, endoscopic findings and treatment
}

\author{
Han $\mathrm{MC}^{1}$, Sağlıyan $\mathrm{A}^{1}$, Polat $\mathrm{E}^{1^{*}}$ \\ ${ }^{1}$ Firat University, Faculty of Veterinary Medicine, Department of Surgery, Elazig, Turkey. \\ * Correspondence: Eren Polat. Üniversite, Fırat Ünv., 23119 Elâzığ Merkez/Elazı̆̆, Turkey. E-mail: \\ erenpolat@firat.edu.tr
}

Received: 27 February 2021. Accepted: 15 April 2021. Available online: 9 June 2021

Editor: P. Beldomenico

\begin{abstract}
SUMMARY. The subject of this study was a dog brought to our clinic with complaints of severe cough, dyspnea and anorexia. During the clinical examination, a hard mass was detected by palpation of the neck area. Vomiting reflex was observed. As a result of radiographic and endoscopic examination, a foreign body was found in the caudal part of the larynx. After the diagnosis was made, the patient was anesthetized and the foreign body was removed with forceps from the oral cavity. During the postoperative period, the patient was administered parenteral antibiotics and intraoral antiseptic for a week. The approach to foreign body cases in the respiratory tract of dogs is discussed.
\end{abstract}

RESUMEN. Un caso de cuerpo extraño traqueal encontrado en un perro Kangal: hallazgos clínicos, radiológicos, endoscópicos y tratamiento. Un paciente canino macho Kangal de 4 meses que fue llevado a nuestra clínica con antecedentes de tos severa, disestrés respiratorio y anorexia. En el examen clínico se determinó que el paciente tenía dificultad para respirar y una masa firme a la palpación de la región del cuello. Se observó que el reflejo del vómito estaba estimulado en el animal. Como resultado del examen radiográfico y endoscópico, se encontró un cuerpo extraño en la región caudal de la laringe. Una vez realizado el diagnóstico, se anestesió al paciente y se extrajo el cuerpo extraño con la ayuda de un laringoscopio. En el postoperatorio, se le administró al paciente antibióticos parenterales y antiséptico oral durante una semana. Se debate el abordaje de casos de cuerpos extraños en el tracto respiratorio de caninos.

Keywords: foreign body, endoscopy, trachea, dog

Palabras clave: cuerpo extraño, endoscopía, traquea, canino

\section{Introduction}

Obstructions of the respiratory tract of dogs may be caused by foreign bodies (Cagatay et al. 2018; Leal et al. 2015; Lewitt et al. 1993). The most common foreign bodies in the respiratory tract include objects such as needles, pieces of wood, pieces of plants, teeth, pebbles, insects, bones, and tracheal tube pieces (Agudelo et al. 2018; Cagatay et al. 2018; Somrup et al. 2017).

Foreign bodies located in the respiratory tract may cause clinical symptoms such as severe cough, dyspnea, anorexia, anxiety, and cyanosis in the patient. In cases where diagnosis and treatment are delayed, it may result in death (Agudelo et al. 2018, Leal et al. 2015; Lewitt et al. 1993; Somrup et al. 2017).

Imaging methods such as radiography, endoscopy and computed tomography can be used to diagnose foreign bodies in the respiratory tract (Leal et al. 2015; Lewitt et al. 1993; Somrup et al. 2017). The location, position and size of the foreign body are important for the its removal. These criteria are important to determine the treatment method. In cases where the foreign body is at the entrance of the trachea, it body can be removed with tracheobronchoscopy, fluoroscopy combined with guided balloon catheter or vacuum applications. Another option is to remove the foreign body with the help of forceps under fluoroscopy. Foreign bodies in the lower respiratory tract can be accessed by tracheobronchoscopy. If the foreign body cannot be removed in this way, surgical options such as thoracotomy and tracheatomy can be used. (Agudelo et al. 2018; Cagatay et al. 2018; Somrup et al. 2017).

In this case report, the diagnosis and treatment stages of a dog with a foreign body detected in the respiratory tract are discussed. 


\section{Case presentation}

In this case report, a dog brought to our clinic (Firat University Animal Hospital, Department of Surgery, Elazig, Turkey) with complaints of severe cough, difficulty in breathing and loss of appetite for three days was discussed. The patient was a 4-month-old Kangal of $23 \mathrm{~kg}$ of body weight.

The clinical examination revealed that the dog had difficulty breathing. During the examination of the dog, it was determined that there was a hard mass in the caudal part of the larynx region. During the palpation of the neck region, a vomiting reflex was observed.

Lateral radiography of the neck region revealed a radiopaque foreign body $3-4 \mathrm{~cm}$ in diameter within the trachea in the caudalis of the larynx (Figure 1). It was decided to perform an endoscopic examination in order to understand exactly what the foreign body was and to determine its accessibility from the oral cavity.

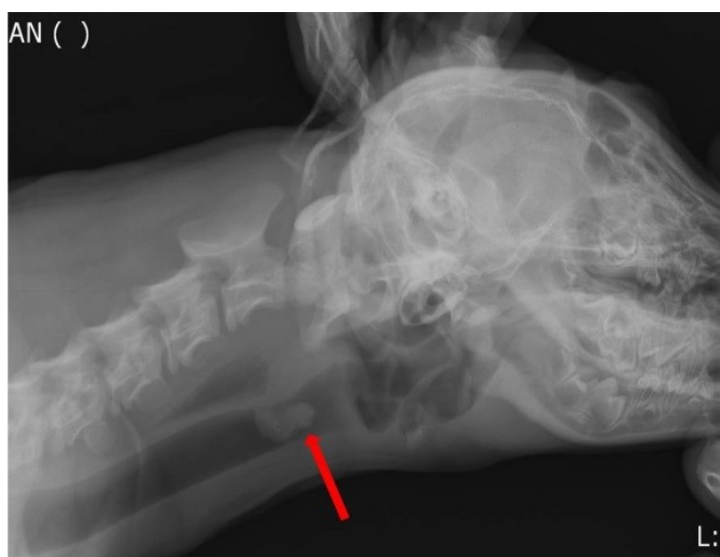

Figure 1. Radiographic view (lateral) of the foreign body (red arrow) in the trachea of a Kangal dog.

For endoscopic examination, $1 \mathrm{mg} / \mathrm{kg}$ dose of xylazine hydrochloride (Rompun, Bayer, $23.32 \mathrm{mg} / \mathrm{ml}$ ) was administered intramuscularly and mild sedation was achieved. In the endoscopic examination, the foreign body in the trachea was found to be a mass of cartilage tissue (Figure 2).

After the examinations, it was decided to remove the foreign body by reaching through the oral cavity. The patient was sedated with $2 \mathrm{mg} / \mathrm{kg}$ xylazine hydrochloride. Then, $20 \mathrm{mg} / \mathrm{kg}$ ketamine hydrochloride (Ketasol, intramuscular, Interhas, $100 \mathrm{mg} / \mathrm{ml}$ ) was administered to achieve the desirable anesthetic plane. Then the tongue of the dog was pulled out and the tongue was pressed down with the aid of a laryngoscope. With the help of the endoscopy device, the foreign body (an articular cartilage) detected at the entrance of the trachea was removed with a suitable forceps (tetrapod foreign body forceps) (Figure 3). After the intervention, the patient was administered penicillin (lecilline, IE Ulugay, 800,000 IU) at a dose of $15,000 \mathrm{lU} / \mathrm{kg} /$ day intramuscularly for five days. In addition, $0.2 \mathrm{mg} / \mathrm{kg}$ of meloxicam (Bavet Meloxicam, Bavet, $5 \mathrm{mg} / \mathrm{ml}$ ) was administered subcutaneously for pain management.

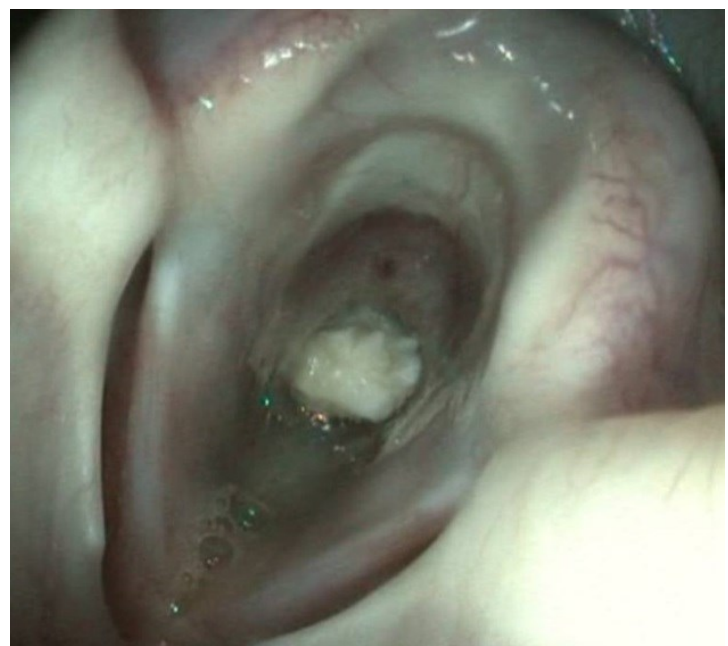

Figure 2. The appearance of the foreign body (an articular cartilage) in the respiratory tract of a Kangal dog during endoscopic examination.

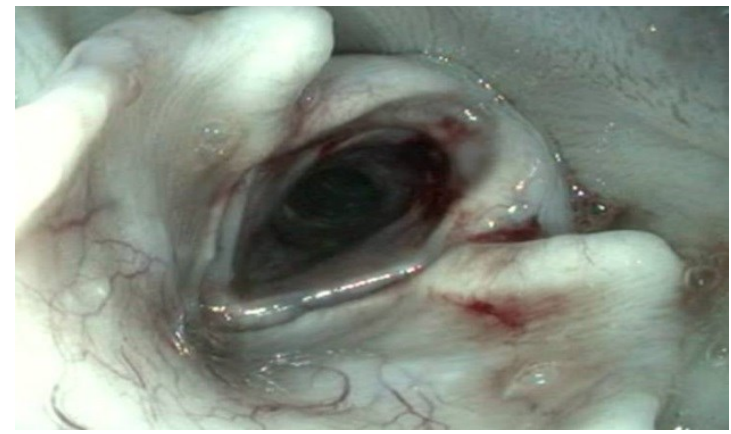

Figure 3. Endoscopic view of the respiratory tract after the foreign body was removed. Petechial hemorrhage foci are observed in the larynx cartilages.

\section{Discussion and conclusions}

Obstruction cases caused by foreign bodies in the respiratory tract of dogs are rarely encountered in veterinary literature (Cagatay et al. 2018; Leal et al. 2015; Somrup et al. 2017). Foreign bodies in the respiratory tract cause clinical findings, especially dyspnea and cough (Agudelo et al. 2018; Leal et al. 2015; Lewitt et al. 1993; Somrup et al. 2017). In this study, the clinical diagnosis and treatment method of a dog with complaints of dyspnea and severe cough was discussed.

Apart from clinical findings, imaging methods have an important role in the diagnosis of foreign bodies in the respiratory tract. Leal et al. (2015) reported that radiographic examinations were $92 \%$ successful in making an accurate diagnosis of foreign bodies in the respiratory system. In this case, as in studies of other researchers (Agudelo et al. 2018; Cagatay et al. 2018; Lewitt et al. 1993; Somrup et al. 2017), the foreign body 
in the caudal part of the larynx was easily detected by radiographic examination. The most important reason why radiographic examinations provide valuable information in the diagnosis of foreign bodies in the respiratory system is the presence of air that provides a natural contrast for many radiopaque objects. In this study, the purpose of using the endoscopic examination was to prevent the possible damage to the surrounding tissues by seeing the structure of the foreign body.

Many techniques are used in the treatment of foreign bodies encountered in the respiratory system. The most preferred among these are tracheabronchoscopy, vacuum and forceps applications accompanied by fluoroscopy (Agudelo et al. 2018; Cagatay et al. 2018). In this case report, the foreign body at the trachea entrance was removed with suitable forceps using endoscopy and laryngoscope.

We conclude that endoscopic examination has an important role in both diagnosis and treatment in obstruction cases caused by foreign bodies in the respiratory system.

\section{References}

Agudelo CF, Filipejova Z, Frgelecova L, Sychra O. 2018. An unusual foreign body in a cat: a case report. Vet. Med. 63: 198202.

Cagatay S, Gokce AP, Yesilovalı G. 2018. Removal of a tracheal foreign body by intercostal thoracotomy in a cat. Vet. Med. 63 : 438-442.

Leal RO, Bongrand Y, Lepoutre JG, Gomes E, Hernandez J. 2015. Tracheobronchial foreign bodies in cats: a retrospective study of 12 cases. J. Fel. Med. Surg. 19: 117-122.

Levitt L, Clark GR, Adams V. 1993. Tracheal foreign body in a cat. Can. Vet. J. 34: 172-173.

Sezer D, Sevim G, iskefli O. 2017. A scottish fold cat foreign body removal via tracheoscopy. K.H.V.H.D. Conferences. İstanbul Üniversitesi Veteriner Fakültesi.

DOI: 10.13140/RG.2.2.21444.73605.

Somrup L, Kompach K, Srisawat W, Akatvipat A. 2017. A case study: the slippery foreign body aspiration in a dog. Chiang Mai Vet. J. 15: 89-97. 